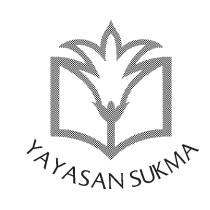

SUKMA: JURNAL PENDIDIKAN

ISSN: 2548-5105 (p), 9590 (e)

Volume 1 Issue 2, Jul-Dec 2017, hlm. 389-411

https://jurnalsukma.org/index.php/sukma/article/view/01207

\title{
BOOK REVIEW \\ Cheating in School: What We Know and What We can Do
}

Fuad Fachruddin

Sekolah Sukma Bangsa Aceh, Indonesia

email: fuadfachruddin5@gmail.com

Title : CHEATING IN SCHOOL: What We Know and What We can Do

Authors : Stephen F. Davis; Patrick F. Drinan; Tricia Bertram Gallant

Publication : J. Wiley \& Sons, UK, 2009

Pages : 240 pages

Cheating (nyontek atau ngepek) merupakan tindakan tidak terpuji atau tindakan tidak jujur alias membohongi orang lain. Seorang siswa yang ngepek secara akademik sama dengan membohongi gurunya agar si guru menganggap karya akademik yang diserahkan oleh siswa yang bersangkutan merupakan karya asli 
dia (p. 2). Cheating merupakan salah satu bentuk atau pewujudan dari academic dishonesty [kebohongan atau ketidakjujuran/ ketidakamanahan akademik] dan ketidakjujuran akademik merupakan salah satu jenis korupsi dalam pendidikan.

Buku ini diterbitkan pada 2009, sehingga buku ini termasuk dalam kategori buku lawas namun isu dan isi pembahasan masih sangat relevan dengan keadaan sekarang terlebih dikaitkan dengan konteks Indonesia. Topik tentang ketidakjujuran akademik siswa dalam buku ini dirancang secara realistik, praktis, dan merupakan refleksi komprehensif tentang keadaan dan upaya kini dan mendatang untuk memberantas praktik nyontek di kalangan siswa pada jenjang pendidikan dasar sampai dengan mahasiswa pascasarjana. Menggiatkan gerakan anti atau melawan ngepek di kalangan siswa tidak hanya penting untuk perbaikan atau transformasi pengajaran namun juga merupakan isu penting bagi perbaikan sistem pendidikan. Dengan kata lain, gerakan pemberantasan nyontek merupakan bagian yang tidak terpisahkan dari reformasi pendidikan.

Secara historis praktek nyontek atau ngepek (ketidakjujuran akademik) terutama dalam dunia pendidikan tinggi menurut Tricia Bertram Gallant yang dikutip Lang (2013:2) dimulai semenjak 1760 sampai sekarang. Bentuk dan jenis ngepek bermacam-macam sejalan dengan perkembangan teknologi. Juga motif atau maksud dan alasan orang-orang yang melakukan ngepek bermacam-macam. Teknik atau cara yang digunakan untuk ngepek bermacam-macam pula, dari cara yang konvensional misalnya menulis kepekan di bagian tubuh seseorang seperti paha atau dalam bra sampai dengan teknik yang canggih yakni memanfaatkan teknologi mutakhir untuk menyontek seperti teknik pager kamera mini, kalkulator terprogram dan skirocketed cell phone (text-messaging). Secara rinci evolusi teknik atau cara nyontek dijelaskan oleh penulis dalam bab empat buku ini.

Buku ini tidak hanya menjelaskan cheating atau nyontek akademik dalam tataran apa yang dimaksud, apa wujud, mengapa nyontek acapkali dilakukan oleh siswa (sekolah) dan mahasiswa 
Book Review: Cheating in School

(perguruan tinggi) namun juga menyajikan cara menghadapi atau mengatasi nyontek. Penulis ini menyajikan bahasan tentang konsep dan jenis strategi (jangka pendek dan jangka panjang) pemberantasan nyontek yang dilengkapi dengan kerangka aksi yang bersandar pada konsep pemberantasan ngepek berbasis stake holder atau melibatkan seluruh elemen komunitas pendidikan dan masyarakat seperti orang tua siswa atau orang tua mahasiswa (partisipatoris).

Mengapa siswa atau mahasiswa nyontek dan apa bentuk serta respon atau pandangan mereka terhadap nyontek. Hal-hal tersebut dibahas dalam bab 1, 2, dan 3. Kerjasama dalam menjawab tugas atau pekerjaan rumah (PR) yang sebenarnya guru mengharuskan masing-masing atau individu siswa bekerja mandiri. Mengambil kata atau ungkapan atau ide orang lain tanpa menyebutkan nama penulis. Menyuruh orang lain menulis paper atau skripsi, tesis atau disertasi [ghostwriting term papers/thesis/dissertation) atau menyelesaikan pekerjan rumah atau test. Menposting soal ujian dari guru ke website atau file tes tanpa izin dari guru. Menulis makalah dengan mengabaikan sumber rujukan yang telah diputuskan guru atau pengajar sebagai tugas baca (seperti cliffnotes, sparknotes). Kesemuanya merupakan contoh praktek perilaku nyontek (p. 4).

Persoalan lain yang terkait dengan nyontek adalah nilai rapor. Angka rapor bisa menjadi salah satu biang keladi yang mendorong seseorang siswa nyontek. Angka rapor menjadi komoditas dalam masyarakat pengetahuan (knowledge community) dan bagi sebagian besar orang tua atau masyarakat umum angka rapor (Indek prestasi atau IP) menjadi representasi tujuan akhir sekolah, karena pada akhirnya nilai rapor (IP) bisa menjadi pertimbangn utama (tiket) untuk mendapatkan penghargaan seperti beasiswa, masuk perguruan atau karir di perusahaan (p. 8).

Gerakan memerangi nyontek tumbuh berkembang sejalan tuntutan era global akan integritas terhadap karya seseorang atau komunitas dan akibat tuntutan kehidupan global yakni bekerja cepat karena kompetisi yang ketat. Hal yang disebut 
belakangan menimbulkan perubahan sikap pada seseorang, misalnya, jalan pintas dalam melakukan sesuatu tugas termasuk karya akademik seperti ngepek. Oleh sebab itu, gerakan pendidikan karakter menjadi penting pada jenjang pendidikan dasar dan menengah, sementara itu gerakan integritas akademik telah menjadi bagian sangat urgen di lingkungan pendidikan tinggi. Di Australia, misalnya, Centre for Academic integrity dan the Josephson Institute of Ethics (p. 24) muncul sebagai respon terhadap persoalan tadi. Gerakan integritas akademik diharapkan dapat memberi moral dasar untuk membangun budaya integritas (integrity culture) di sekolah dan perguruan tinggi ( $\mathrm{p}$. 28).

Nyontek atau ngepek telah berlangsung lama dalam kehidupan manusia dan bahkan dianggap sebagai endemic. Penulis menyebutkan praktek ngepek dapat ditelusuri dari asal mula gerakan standarisasi tes pada era Cina Kuno dan di Amerika sendiri praktek nyontek (academic misconduct) dimulai dari abad 18 sampai abad 21 ini (p. 36). Pada abad 18, siswa-siswi yang merasa takut gagal dalam sekolah dan takut mendapatkan olok-olokan dari teman-teman atau orang lain (merasa malu dan dipermalukan), nyontek merupakan cara untuk menyelamatkan kehilangan muka (save face) di kalangan teman sejawat dan untuk mempertahankan harga diri (one's sense of personal honor) karena membohongi guru jauh lebih baik (harga diri) ketimbang gagal dalam kelas atau belajar. Pada abad ini diploma atau ijazah palsu (diploma mills) menjadi suatu yang biasa di Amerika, sehingga seseorang siswa yang dikeluarkan dari sekolah lantaran ngepek bisa dapat menyelamatkan diri dengan mendapat diploma atau ijazah aspal yang dapat menjadi tiket untuk mendapatkan pekerjaan (p. 37 )

Pada abad ke 19 dan menjelang awal abad 20, jumlah mahasiswa-mahasiswi di kampus-kampus meningkat dan para mahasiswa-mahasiswi mulai melihat atau merasakan mata kuliah dan tugasnya sebagai suatu beban berat atau hambatan yang perlu diselesaikan agar seseorang membuat kemajuan personal dan professional atau akademik di universitas mereka 
Book Review: Cheating in School

kuliah. Keadaan ini dapat membuat seseorang (mahasiswa) mengambil jalan pintas dalam mengatasi beban akademik dengan mengepek. Sekitar 40 persen mahasiswa-mahasiswi terlibat nyontek (academic cheating) dalam era ini. Banyak anak muda perempuan dan laki-laki (mahasiswa-mahasiswi) yang berasal dari keluarga terhormat tidak sedikitpun merasa ragu untuk menyerahkan makalah dan tesis yang disiapkan atau dibuatkan oleh seseorang (crib) untuk bahan ujian (p. 37).

Pada pertengahan abad 20, lembaga pendidikan tinggi tumbuh dengan subur (banyak) dengan ragam program studi dan jumlah mahasiswa meningkat. Perubahan secara dramatis jumlah perguruan tinggi di Amerika berbarengan dengan turbulansi Vietnam dan era Watergate telah membawa peningkatan praktek nyontek. Jumlah makalah yang diperjualbelikan (term paper mills), misalnya, telah memfasilitasi siswa, mahasiswa melakukan ngepek dan ekspose sumber tesebut telah mendorong para pengajar di negara-negara belahan bumi ini untuk melaporkan para siswa atau mahasiswa yang melakukan plagiasi berkali-kali. Sebagai contoh, hasil survey William terhadap 5,422 mahasiswa doktoral di 99 perguruan tinggi Amerika antara tahun 1962-1963 menunjukkan bahwa 56 persen melakukan plagiasi dan 44 persen melakukan ngepek (p. 38).

Pada kurun waktu lewat sedikit pertengahan abad 20, banyak mahasiswa-mahasiswi Amerika menyontek untuk karir pendidikan. Survei Fred Schab, Professor Emeritus Universitas Georgia, terhadap 4.000 siswa sekolah menengah antar tahun 1969 dan 1989 menunjukkan bahwa jumlah mahasiswa melaporkan atau menyatakan dirinya nyontek meningkat dan menganggap nyontek sebagai hal yang biasa dilakukan pada kurun waktu tersebut (p. 38). Secara ringkas dikatakan bahwa nyontek merupakan fenomena perennial sebagai upaya seseorang (siswa) untuk survive berhadapan dengan jumlah siswa yang cenderung meningkat (populasi). Ngepek di kalangan siswa terjadi dan bahkan berkat kemajuan teknologi jumlah siswa ngepek meningkat. Juga pengertian atau definisi siswa ngepek (student cheating) telah berkembang dari pengertian ngepek abad 19 ke 
pengertian lebih jauh, yakni plagiasi dan unauthorized collaboration yang sebelum pertengahan abad 20 belum dikenal (p. 40).

Bagaimana gambaran nyontek pada awal abad 21? Dengan merujuk kepada hasil survey The Josephson Institute of Ethics pada 2006 dan 2008, penulis buku ini menjelaskan bahwa persentasi siswa ngepek (student cheating) tidak berubah dan bahkan meningkat sedikit dari hasil survey pada 2004. Nyontek (academic cheating) meningkat dibanding dengan bentuk ketidakamanahan lainnya atau misconduct seperti mencuri atau cheating dalam dunia olah raga. Banyak siswa lebih terus terang mengakui bahwa mereka melakukan nyontek di kelas ketimbang tindakan misconduct lainnya. Sedangkan mahasiswa yang mengepek dapat dilihat dari data hasil survey McCabe terhadap 80,000 mahasiswa Amerika dan Kanada antara 2002 dan 2005 yang menunjukkan bahwa 21 persen mahasiswa S1 melakukan ngepek dalam bentuk, seperti mengopi, menggunakan catatan kepekan dan atau membantu teman mengepek paling tidak sekali dalam satu periode, 5 persen mengepek dengan menggunakan alat elektronik atau digital dalam ujian. Hanya 10 persen mahasiswa pascasarjana mengakui mengepek dengan, misalnya, mengopi, menggunakan catatan kepekan dan atau membantu teman sekali dalam satu periode dan 2 persen mengepek dengan menggunakan alat elektronik atau digital. Sedangkan hasil survey McCabe menunjukkan bahwa 50 persen mahasiswa melakukan plagiasi dan fabrikasi dan melakukan kebohongan terkait dengan sumber rujukan. Sebanyak 8 persen mengaku melakukan ngepek dengan mengopi karya orang sekali dalam satu periode (p. 43).

Praktek academic dishonesty dapat tumbuh karena lingkungan yang permisif terhadap, misalnya, praktek ghost written paper, nyontek dalam ujian, ngumbar nilai atau sangat murah memberi nilai, ngobral kenaikan tingkat luar biasa, bantuan orang dalam mengerjakan PR. Juga staf membantu para siswa menyontek (untuk mendapat kick back). Dengan memberikan soal ujian sebelum waktunya, mengubah hasil ujian (meluluskan siswa/mahasiswa yang tidak lulus ujian) atau memberikan jawaban ujian kepada para siswa, memberikan ijazah palsu (fake 
Book Review: Cheating in School

certificate) merupakan praktek ketidakjujuran akademik yang membawa ke posisi ambang praktek korupsi dalam pendidikan (lihat Hallak \& Poison, 2007). Dengan kata lain, ngepek menjadi cikal bakal pratik korupsi dalam pendidikan. Pendapat tersebut diperkuat oleh temuan Diana Amsden bahwa terdapat hubungan antara siswa-siswi ngepek dengan korupsi dalam pendidikan secara keseluruhan (p. 61).

Mengapa siswa nyontek? Secara umum penulis menyimpulkan bahwa kebohongan atau ketidakjujuran akademik meningkat drastis (eskalatif) lantaran orang tua dan guru gagal mengajar, melaksanakan, menanamkan dan mengadvokasikan secara cerdas contoh integritas diri (model personal integrity) ( $p$. 33). Nyontek bukan semata lantaran sikap anak, namun nyontek terjadi lantaran sistem yang korup yang dalam sistem tersebut orang tua, guru dan pengelola sekolah tidak setuju dengan penerapan aturan atau tuntutan integritas akademik dalam situasi apapun (p.61).

Juga penulis menjelaskan beberapa faktor yang mendorong seseorang melakukan nyontek yang dibagi ke dalam dua kategori yaitu faktor eksternal dan faktor internal. Faktor eksternal adalah faktor yang ada di luar diri seseorang dan mendorong seseorang (siswa) melakukan nyontek, misalnya, ruang kelas yang padat memungkinkan seorang siswa melakukan nyontek. Dalam kelas yang berjubel memungkinkan seseorang siswa menyontek hasil tes siswa lain atau saling menyontek. Keadaan ini lebih problematic kalau tes yang diberikan pada para siswa berbentuk pilihan ganda (p. 75). Siswa nyontek didorong oleh tuntutan mendapat angka rapor (IP) tinggi yang bisa menjadi tiket untuk masuk perguruan tinggi atau dunia kerja. Nyontek menjadi strategi bagi siswa-siswi untuk mempertahankan diri (survival) dalam menghadapi kompetisi (p. 73).

Faktor internal mencakup berbagai hal yakni keterbatasan pada seseorang seperti waktu, sikap dan pandangan seseorang terhadap tindakan yang dilakukan, sikap diri dan sikap yang dibentuk oleh keadaan atau faktor eksternal. Seseorang nyontek 


\section{Fuad Fachruddin}

lantaran waktu yang dimiliki sangat terbatas, misalnya, siswa kelas karyawan atau mahasiswa kelas karyawan (kasus Indonesia). Bagi siswa atau mahasiswa yang memiliki waktu terbatas (seperti siswa atau mahasiswa kelas karyawan-kasus Indonesia) nyontek dilakukan untuk survival dalam belajar dan dengan nyontek seseorang akan menghemat waktu belajar. Dengan ngepek, ia hanya menggunakan sepuluh menit (misalnya) dapat memperoleh hasil setara dengan belajar dua jam (p. 74).

Juga seorang siswa menyontek lantaran ia melihat sesuatu yang tidak sesaui dengan harapannya, misalnya, mata pelajaran tidak mempunyai arti atau manfaat baginya, sangat sulit, atau sangat mudah (p. 73), Seseorang nyontek lantaran teman-teman sekelas melakukan tindakan nyontek. Sikap pembenaran diri terhadap tindakan nyontek disebut dengan neutralization. Neutralization menunjuk kepada kenyataan (fakta) bahwa banyak siswa-siswi berusaha melakukan pembenaran terhadap prilaku nyontek mereka dengan alasan nyontek dilakukan oleh kebanyakan siswa-siswi (p. 72). Acapkali muncul sikap dalam seseorang bahwa nyontek boleh-boleh saja asalkan "tidak ketahuan " oleh guru atau pengawas. Apabila pandangan seperti ini muncul kuat dalam masyarakat, orang-orang yang melakukan praktek akademik tidak jujur atau tidak amanah akan bertambah atau berkembang (p. 76).

Ada beberapa faktor determinan yang mempengaruhi perilaku nyontek, seperti perbedaan gender, kecerdasan, etika kerja dan perkembangan moral, motivasi dan sikap butuh persetujuan orang lain. Laki-laki dilaporkan lebih dominan melakukan nyontek ketimbang perempuan. Mereka mengakui bahwa mereka sering nyontek karena mereka laki-laki dan mereka menemukan diri mereka dalam "budaya nyontek" (p. 77). Anakanak (siswa-siswi) yang memiliki kecerdasan tinggi yang diukur dengan IQ sedikit melakukan nyontek ketimbang anak-anak yang mempunyai kecerdasan rendah (p. 77). Anak-anak (siswa-siswi) yang memiliki etos kerja tinggi dan moral tinggi sedikit sekali melakukan nyontek ketimbang anak-anak (siswa-siswi) yang memiliki etos kerja dan moralitas rendah. Anak-anak (siswa- 
Book Review: Cheating in School

siswi) yang memiliki motivasi belajar dan prestasi akademik tinggi (mencari ilmu atau belajar) jarang melakukan nyontek ketimbang mereka yang motivasi sekolah untuk mendapatkan angka rapor baik atau IP tinggi atau mendapat gelar semata banyak melakukan nyontek. Juga mereka yang didorong motivasi eksternal kuat banyak melakukan nyontek (p. 78). Anak-anak yang memiliki sikap ingin mendapatkan persetujuan orang lain atau dikendalikan kekuatan luar dalam melakukan tindakan lebih banyak melakukan praktek nyontek ketimbang anak-anak yang memiliki sikap mandiri dalam membuat keputusan. Juga anak-anak yang memiliki tanggung jawab rendah suka menunda-nunda tugas (Procrastination (delay) and responsibility) atau menyelesaikan tugas dalam last minute work banyak melakukan menyontek dibanding dengan anak-anak yang penuh tanggung jawab dan berusaha menyelesaikan tugas tepat waktu atau in time atau on time (p. 80).

Selain sikap tersebut, ada sikap yang muncul di kalangan siswa yang disebut dengan victimless crime. Mereka memandang bahwa nyontek bermanfaat bagi mereka dan mereka menganggap tindakan ini (nyontek) tidak mempengaruhi orang lain atau mereka menganggap tidak ada orang yang disakiti karena mereka menyontek (p. 84, 87). Di kalangan mahasiwa, muncul perubahan pandangan tentang ghostwriting term papers. Banyak mahasiswa kini memandang tindakan ini tidak salah atau melanggar aturan karena mereka membeli paper atau tesis yang ditulis oleh biro jasa atau orang yang disuruh untuk melakukan tersebut, misalnya, paper atau tesis atau disertasi yang mereka jual belikan sah-sah saja karena property (kekayaan) mereka, mahasiswa menyerahkan paper atau tesis atau disertasi kepada pengajar. Jadi tidak ada suatu kesalahan bagi seorang mahasiswa yang memanfatkan ghostwriting term papers untuk memenuhi kewajiban (p. 85) dan tidak ada orang yang disakiti. Secara ringkas, penulis buku ini menyimpulkan bahwa sikap, nilai dan moral telah mengalami perubahan di kalangan siswa dan mahasiswa yang terlibat dalam praktek ketidakjujuran atau kektidakamanahan akademik. Banyak siswa atau mahasiswa 
menganggap nyontek sesuatu yang tidak dilarang (tidak haram) untuk menyelesaikan studi (p. 86).

Menyimak uraian tersebut di atas, kita dapat memahami bahwa gerakan pemberantasan nyontek tidak mudah dilakukan karena banyak faktor, antara lain, sikap permisif dari orang-orang tentang nyontek dan nyontek dianggap tidak merusak masyarakat. Juga sikap seseorang yang tidak suka nyontek namun tidak memiliki sikap geregetan terhadap pelaku nyontek atau membiarkan atau tidak ada gerakan yang diinisiasi oleh mereka (p. 86) yakni orang-orang tersebut tidak menjadi agent of change untuk mencegah kemungkaran alias mereka hanya menjadi penonton atau hanya mampu melontarkan kritik. Dalam bahasa akhlak Islam, orang yang berperilaku seperti ini adalah orang saleh untuk dirinya (shalih fi dzati nafsihi) tetapi tidak saleh untuk orang lain. Padahal untuk melakukan gerakan kebaikan untuk masyarakat atau bangsa diperlukan orang baik untuk dirinya dan baik bagi orang lain (shalih fi dzati nafsihi wa shalih lighairihi). Kegagalan membendung atau memberantas nyontek atau segala praktik ketidakjujuran lantaran orang tua dan guru gagal mengajar, melaksanakan, menanamkan dan mengadvokasikan secara cerdas contoh integritas diri (model personal integrity) sebagaiama diungkapkan di muka (p. 33).

Lingkungan secara umum (makro atau nasional) koruptif juga menjadi penghalang terhadap pemberantasan nyontek dan segala tindakan academic dishonesty. Oleh sebab itu, dalam lingkungan koruptif tidak banyak orang mempersoalkan orang lain yang mendapat gelar akademik secara tidak wajar, atau lembaga pendidikan memberi banyak sekali kemudahan seseorang memperoleh gelar akademik tanpa seseorang menempuh perkuliahan yang sebenarnya; penguji skripsi, tesis atau disertasi secara diam-diam (rahasia) memberi catatan tentang pertanyaanpertanyaan ujian kepada promovendus sehingga promovendus dapat menjawab pertanyaan dengan baik pada waktu ujian promosi. Oknum individu pengajar atau dosen atau lembaga yang melakukan praktek academic dishonesty justru merupakan musuh dalam selimut terhadap academic honesty atau integrity 
culture dalam pendidikan dan gerakan pemberantasan korupsi dalam pendidikan secara menyuluruh (lihat Hallak \& Poison, 2007).

Memang tidak mudah untuk menjalankan gerakan melawan ngepek apalagi korupsi pendidikan. Kita, para pendidik, harus berusaha keras melakukan upaya sikap intoleran terhadap nyontek pada tingkat kelas atau sekolah (mikro). Penulis buku menyajikan ide-ide berkaitan dengan pemberantasan nyontek dalam jangka pendek. Misalnya, kita (guru) dapat menerapkan aturan tidak boleh ngepek di kelas dan menciptakan lingkungan yang mendukung untuk menumbuhkan integritas akademik dan menangani academic misconduct yang dilakukan oleh siswasiswi. Untuk itu, guru hendaknya bekerja sama dengan elemen masyarakat sekolah lainnya. Juga pengajar atau dosen beker. jasama dengan civitas akademik dan elemen masyarakat lainnya Dalam kontek ini, penulis menyampaikan beberapa hal penting yaitu (a) teknik yang digunakan untuk mendeteksi nyontek, (b) jawaban yang tepat dan tidak tepat dan (c) jenis hukuman yang harus atau layak diberikan ke pelaku nyontek dengan tingkatan (p. 107).

Untuk mencegah praktik nyotek dalam tes, penulis mengajukan beberapa teknik, seperti observasi (mengamati) kelas, hanya saja metoda ini ada kelemahan yaitu bukti untuk menjerat seseorang melakukan nyontek (p. 108) tidak mudah diperoleh. apalagi dalam kelas besar yang melebihi ketentuan ideal suatu kelas. Sekolah atau guru dapat menggunakan software untuk mendeteksi nyontek dalam tes termasuk yang di dalamnya peringatan dini terutama digunakan untuk (a) melihat siswa yang nyontek dalam mengerjakan tes pilihan ganda, (b) mem. bandingkan hasil tes pilihan ganda dan tes betul salah dan (c) menggunakan K-index untuk menetapkan siapa yang nyontek jika jawaban yang tidak betul dari dua orang mengambil tes yang sama atau item yang sama dari dua orang atau lebih (p. 109).

Penulis mengajukan beberapa cara atau teknik untuk mendeteksi plagiasi, misalnya, membandingkan makalah yang ditulis 


\section{Fuad Fachruddin}

oleh siswa atau mahasiswa dalam satu kelas atau dengan kelas setara, membanding paper yang ditulis siswa atau mahasiswa dengan buku atau jurnal yang memuat isu yang sama. Juga guru/ dosen dapat mengirimkan tulisan tersebut ke perpustakaan dan meminta petugas pustaka untuk mengecek rujukan yang dikepek. Guru atau dosen dapat menggunakan software komputer untuk mendeteksi plagiasi, misalnya, sistem prevensi plagiasi terpadu Turnitin untuk paper yang diduga mengandung plagiasi ( $\mathrm{p}$. 111). Juga guru memggunakan laporan Turnitin untuk mendeteksi paper yang memerlukan pemeriksaan lebih dalam (p.112). Program Turnitin digunakan untuk mendeteksi laporan laboratorium. Untuk mendeteksi siswa-siswi yang nyontek dalam kelas online guru dapat menggunakan program deteksi kelas online. Persoalan yang sering dihadapi adalah dosen kurang memperhatikan hal ini dan banyak dosen hanya mengumpulkan alasan saja tanpa melakukan langkah lanjut (p. 114).

Sekolah atau fakultas dapat mengenakan hukuman terhadap pelaku nyontek sebagai berikut: diskualifikasi atau tidak lulus dalam ujian/tes, tidak naik kelas, diberhentikan sementara (dirumahkan sementara), atau membuat tanda dalam transkrip nilai siswa-siswi yang nyontek, memberikan sanksi yang mendidik agar pelaku nyontek dapat melakukan perbaikan sikap (p. 116). Anak tertangkap basah sewaktu ujian merupakan kasus yang sensitif dan eksekusi terhadap pelaku nyontek biasanya dilakukan setelah ujian selesai. Penanganan seperti ini mengandung sesuatu yang positif terutama terhadap pelaksanaan ujian yakni pelaksanaan ujian tidak terganggu dengan kasus yang terjadi (p. 116). Cara lain adalah mengambil kertas kerja siswa-siswi yang nyontek dan diberi soal lagi untuk mulai lagi (tindakan sangat lunak). Hukuman lain adalah siswa-siswi atau mahasiswa-mahasiswi nyontek dikeluarkan dari sekolah atau universitas yang bersangkutan (p. 117).

Penulis juga mengajukan beberapa contoh tindakan pemberantasan nyontek dalam jangka pendek yaitu (a) menghentikan, tindakan ini seperti band aid, (b) melakukan kajian tentang cara-cara yang mendorong para siswa-siswi atau mahasiswa- 
mahasiswi tidak tertarik melakukan nyontek, plagiasi, memalsu laporan laboratorium dan nyontek di kelas online (p. 117). Ada berapa cara yang dilakukan dalam tes, misalnya, (a) guru memberikan bentuk soal tes berbeda kepada masing-masing siswa-siswi, (b) guru memberikan woro-woro tentang larangan nyontek, (c) mengatur tempat duduk siswa-siswi dengan mengosongkan bangku antara seorang peserta ujian dengan lainnya, (c) guru jalan mengelilingi (patrol) kelas untuk mencegah murid memanfaatkan kelengahan guru atau pengawas dan (d) guru mengawasi secara cermat siswa-siswi yang tengah mengerjakan soal-soal ujian (p. 118). Pengajar meminta mahasiwa-mahasiswi untuk menyimpan barang-barang mereka seperti tas, botol minum, tempat makanan, alat komunkasi di depan kelas. Mahasiswa-mahasiswi tidak diperkenankan membawa alat-alat elektronik atau komunikasi, memakai topi atau kacamata hitam (p. 122).

Untuk menghindarkan mahasiswa-mahasiswi melakukan plagiasi, pengajar atau dosen dapat memberikan tugas berlainan untuk masing-masing individu mahasiswa-mahasiswi yang berkaitan dengan kehidupan dirinya (p. 124). Untuk menghindarkan mahasiswa-mahasiswi melakukan plagiasi dalam laporan lab, pengajar atau dosen mensosialisasikan budaya riset dengan membanding riset lab dan riset non-lab atau di masyarakat. Dosen membaca satu per satu laporan yang dibuat mahasiswamahasiwi. Mahasiswa-mahasiswi diminta melakukan tugas dengan prosedur yang tidak biasa, misalnya mahasiswa-mahasiswi diminta menyelesaikan tugas dalam waktu pendek (ketat); berkaitan dengan metodologi dosen minta mahasiswa-mahasiswi menjelaskan apa yang dilakukan mahasiswa-mahasiswi sewaktu mereka melakukan tes atau percobaan; dalam kaitan dengan data, dosen meminta mahasiswa-mahasiswi menjelaskan apakah ia menemukan skor yang ekstrim dan tidak ekstrim dan berapa skor yang ekstrim-dengan cara demikian pembohongan data dapat ditekan (p. 126). Untuk mendeteksi nyontek mahasiswa-mahasiswi dalam kelas online, dosen dapat melakukan beberapa cara, misalnya, menggunakan instrumen tes standar 
(pilihan ganda, matching, esai atau self-assement, masing-masing diminta aktif dalam diskusi online, menggunakan tugas pribadi dan penyerahan tugas on time (p. 126).

Penulis mengajukan ide penanganan (pemberantasan) nyontek jangka panjang. Pembangunan moral dan pelembagaan integritas akademik dinilai sebagai pendekatan yang paling menjanjikan untuk mengatasi problem siswa nyontek dalam jangka panjang. Pengembangan integritas individu dan institusi merupakan pendekatan pertama. Tugas lembaga bukan mendeteksi penyontek tapi menciptakan lingkungan yang tidak toleran terhadap ketidakjujuran akademik (academic dishonesty). Penanaman atau pengembangan sikap tidak toleran terhadap nyontek (moral) utamanya di kalangan siswa-siswi dan guru dan pelembagaan integritas dalam organisasi pendidikan. Mengapa pengembangan moral di kalangan individu dan institusi? Penulis menjelaskan pillihan tindakan sangat dipengaruhi oleh minat dan kebutuhan yang acapkali bertentangan satu dengan yang lain dan pilihan tersebut merupakan keputusan yang didasarkan pada moral agung (p. 134).

Lembaga pendidikan dapat membantu para siswa atau mahasiswa pertama-tama mengenal perilaku moral seperti kejujuran) dan ketidakjujuran (seperti nyontek), selanjutnya berdasarkan nilai tersebut seseorang siswa-siswi atau mahasiswa-mahasiswi membuat keputusan dalam menghadapi persoalan etika (ethical dilemma). Sekolah, menurut teoretisi pengembangan moral, dapat berperan dalam mengembangkan empat komponen tindakan moral kepada para siswa, yaitu sensitivitas moral, keputusan moral, motivasi moral dan perilaku moral. Untuk mengembangkan masing-masing komponen, sekolah, perguruan tinggi atau universitas perlu memperhatikan dan sedia melakukan intervensi tentang integritas moral untuk melawan nyontek ((p. 135). Orang tua siswa-siswi bersama warga masyarakat memberikan kebebasan kepada sekolah melakukan tindakan melawan nyontek atau academic dishonesty (p. 138)membantu siswa mengembangkan sensitivitas moral, keputusan moral dan motivasi untuk mengamalkan integritas; membantu 
para siswa dengan "self-binding"; mengajarkan bagaimana mengatasi problem etik (ethical dilemma) kepada para siswa-siswi; meningkatan profitabilitas integritas akademik-keuntungan besar mempertahankan integritas akademik; membuat brand integritas akademik dan mengikuti atau memasukkan etik guru (the ethical conduct) (p. 139].

Membantu para siswa-siswi untuk self-bind, yakni membangun kebiasan yang baik merupakan kunci perbaikan. Perbaikan diri perlu lebih ditekankan lebih dari pemberian makanan dan latihan. Kebiasaan mendukung integritas akademik harus menjadi poin utama dalam menangani epidemik siswa nyontek (p. 140). Para siswa-siswi didorong untuk mensinergikan minat atau kepentingan pribadi dengan kepentingan masyarakat ketika ia atau mereka diminta untuk berjuang memperoleh nilai yang baik dengan penyelesaian tugas secara terpuji. Tindakan tersebut merupakan upaya guru membantu siswa-siswi mengatasi problem etik (p. 141). Membantu teman dengan berpegang teguh pada aturan, seperti memberi semangat teman-teman, meminta bantuan guru, memberi tutorial namun tidak memberi jawaban soal atau tes (p. 141). Membantu para siswa-siswi menyeimbangkan orentassi berprestasi dan keinginan berhasil dengan belajar dalam membuat keputusan pribadi dan tanggung jawab. Lembaga pendidikan dan orang tua bertanggung jawab mengajar siswa-siswi bagaimana merespons secara etis terhadap evaluasi yang tidak fair dan guru yang bersikap dan tindak tidak adil. Sekolah harus menempatkan kebijakan dan prosedur yang membantu orang tua dan siswa-siswi berbuat adil. Para siswasiswi didorong untuk mengamalkan moral yang diajarkan melalui, antara lian, memberi ganjaran terhadap orang yang menaati integritas akademik dan hukuman terhadap orang yang melanggar integritas akademik (p. 142).

Juga guru dapat mengajarkan siswa-siswi bahwa mempertahankan integritas akademik memberi manfaat baik. Siswa-siswi yang melakukan nyontek atau sikap tidak jujur akan memperoleh grade tinggi namun juga beresiko tinggi atau mengorbankan guru dan siswa-siswi yang menjunjung integritas akademik (p. 
145). Kalau siswa-siswi nyontek agar ia dapat diterima di perguruan tinggi, perguruan tinggi harus memanfaatkan hal itu untuk menggalakkan penolakan nyontek dan mengadvokasikan integritas akademik (p. 146). Para guru hendaknya didukung dalam melakukan pemantauan terhadap ketidakjujuran akademik dan mengajarkan nilai-nilai yang berkaitan dengan integritas akademik, juga memberi penghargaan terhadap mereka yang membangun budaya integritas di kelas dan mengembangkan nalar moral dan prilaku baik kepada para siswa-siswi (p. 147). Juga kampus memberi penghargaan terhadap mereka yang mempertahankan integritas akademik dan memberi penghargaan saat wisuda dengan menyematkan tanda khusus dalam transkrip nilai (p. 148). Hal-hal tersebut termasuk dalam upaya meningkatkan profitabilitas integritas akademik.

Branding integritas akademik terkait dengan membangun keadilan, yaitu loyal terhadap integritas akademik, sadar akan integritas akademik dan memilliki pemahaman bahwa mutu merupakan integritas akademik (p. 149). Keadilan sebagai brand dapat dikembangkan ketika institusi mempunyai nilai, norma, keyakinan yang secara terus menerus dikumandangkan dan didorong melalui simbol, bahasa, narasi, dan praktik. Sekolah didorong untuk mengembangkan keadilan. Brand tentang integritas, pelembagaan simbol, dan ritual seperti kode penghormatan, seremoni penyematan penghargaan yang dituliskan oleh para siswa-siswi dalam setiap tugas (p. 150), Pengajar atau dosen dan administrator bahu membahu dalam mengembangkan dan mengartikulasikan tanggung jawab etis dan kewajiban professional guru. Semua kebijakan integritas akademik menuntut dosen melaporkan siswa nyontek. Kesemua ini merupakan bagian dari etika professional guru (p. 155).

Strategi kedua adalah melembagakan integritas akademik. Ada beberapa tahapan dalam hal ini, yaitu: tahap pertama pengenalan dan komitmen, yaitu organisasi pendidikan mesti mengenal bahwa ada isu dan komitmen yang perlu diperhatikan. Ada ketidakpuasan dengan keadaan dan dialog antarpengajar dan administrator tentang integritas akademik sangat minim (p. 156). 
Book Review: Cheating in School

Hal-hal tersebut perlu dikenali terlebih dahulu sebelum kita melangkah lebih jauh. Strategi kedua adalah menggenerasi jawaban yaitu mengkaji problem secara mendalam dan mengstrukturkan pembicaraan tentang bagaiamana mengatasi problem ketidakjujuran akademik. Nyontek bukan hanya kegagalan moral dan problem individu namun persoalan yang menuntut perhatian seluruh elemen organisasi (p. 158).

Tahap ketiga adalah pelaksanaan. Tahap ini dapat terlaksana ketika hal utama dalam organisasi pendidikan terutama guru dan kepala sekolah/dekan telah mengintegrasikan inovasi integritas akademik dalam prosedur operasional standar (SOP). Guru perlu mengetahui secara pasti apa yang dibutuhkan untuk melawan nyontek dan mempunyai keyakinan bahwa para administrator akan mendukung gerakan pemberantasan nyontek (p. 159).

Tahap keempat adalah pelembagaan yaitu melangkah lebih dari pelaksanaan menuju kepada pengintegrasian akademik dalam kehidupan kampus. Dalam tahap ini, beberapa tindak nyontek mungkin masih terjadi, namun masyarakat kampus tahu bagaimana mengahadapi atau mengatasi academic dishonesty dan mempertahankan integritas secara konsisten dan teguh serta mempropagandakannya. Kerjasama antara mahasiswa, dosen, dan administrator akademik berjalan efektif untuk melembagakan tugas ini. Keberhasilan tugas ini dapat terwujud apabila semua civitas akademik atau komunitas perguruan tinggi mempunyai pemahaman yang sama tentang bagaimana seharusnya kampus sebagai integritas akademik atau budaya akademik atau mendapat brand sekolah atau kampus berintegritas atau memperjuangkan integritas akademik (p. 159).

Dalam bab tujuh, penulis menyuguhkan kerangka aksi untuk memberantas nyontek. Penulis banyak menggunakan percakapan untuk menstimulasi para siswa-siswi, guru, administrator dan lain-lain ke tingkat kesadaran dalam melakukan aksi untuk mengatasi ketidakjujuran akademik di kalangan siswa-siswi/mahasiswa-mahasiswi. Teachable moment meru- 


\section{Fuad Fachruddin}

pakan pendekatan dalam menumbuhkan kesadaran di kalangan siswa-siswi, mahasiswa-mahasiswi bahwa nyontek merupakan pelanggaran akademik atau integritas akademik. Percakapan merupakan kunci yang menghubungkan seluruh stakeholder untuk membangun dan mempertahankan integritas lembaga pendidikan.

Penulis mengetengahkan kasus seorang mahasiswi tahun pertama, Sally, yang menyontek dalam mata kuliah "menulis karya ilmiah". Profesor mengingatkan bahwa dia tidak lulus dalam mata kuliah tersebut dengan cara tegas dan bijak. Professor memanfaatkan tindakan sebagai momen (teacheable moment) untuk menumbuhkan kesadaran Sally, yakni menghargai dan mempertahankan integritas akademik. Dosen Sally tidak mengutuknya dan menyebutnya penyontek, namun membangun kesadaran Sally dengan menjelaskan mengapa mengopi dan mengambil ide orang lain tanpa menyebutkan penulisnya dilarang. Juga ibunya Sally tidak mencoba mempertahankan anak perempuannya dan tidak menyerang lembaga pendidikan atau pengajar, namun ia berusaha mendukung Sally bahwa ia harus menempuh dan mengalami konsekuensi dari pilihannya (p. 179). Administrator atau bagian kemahasiswaan bertindak sebagai penuntun dengan menarik hikmah (pembelajaran) dari kasus nyontek sebagai kesempatan untuk mengubah pemikiran kepala bagian akademik tentang solusi terhadap persoalan plagiasi di kampus. Pendidik dan orang tua perlu menginisiasi teachable moment dan melanggengkannya untuk menumbuhkan kesadaran pelanggar kejujuran akademik. Kearifan siswa-siswi akan muncul ketika guru dan orang tua menyuarakan pentingnya integritas secara terus-menerus dalam percakapan yang panjang (p. 180).

Menumbuhkan kesadaran bahwa nyontek merupakan isu moral (kebajikan) dan harus disosialisasikan ke dimensi kehidupan lain seperti ekonomi. Bagi pelaku ekonomi, khususnya mereka yang bergerak dalam knowledge based economy, moralitas atau kebajikan menjadi bagian yang tidak dapat dipisahkan dalam kegiatan ekonomi. Kesadaran atau kebijakan (wisdom) dibangun dengan tiga cara, yaitu: (a) mendorong orang untuk 
melakukan refleksi, (b) menanamkan perilaku yang memajukan integritas, dan (c)membangun lembaga yang berfungsi sebagai pusat informasi, pengetahuan dan kearifan yang dapat mendorong kemajuan intelektual dan moral. Refleksi terhadap dampak eksploitasi informasi dan pengetahuan terhadap pemahaman para siswa-siswi, mahasiswa-mahasiswi tentang integritas akademik. Dalam konteks nyontek, refleksi merupakan cara yang lebih efektif untuk menyasar konsepsi mereka tentang pengetahuan dan informasi sebagai sesuatu yang menempati suatu ruang antara masa lalu dan mendatang dan tubrukan antara ide dan praktiknya dalam realita (p. 182).

Langkah menanamkan perilaku dapat dimulai seperti proses mengisi gelas. Misalnya, sekolah dan perguruan tinggi mulai mengenali perilaku yang menyimbolkan integritas akademik dan memberi penghargaan kepada siswa-siswi, para guru, dan administrator yang telah berkomitmen mengamalkan etika akademik. Karyawan dan alumni dapat mendorong kejujuran dan integritas dengan tidak menekankan angka rapor atau IP, namun belajar (mutu) dan memberi penghargaan terhadap siswa-siswi yang mendorong secara kuat sikap dan keberanian melawan nyontek serta mengembangkan ide individu dan berpikir kreatif serta berpikir kritis. Langkah ketiga adalahmembangun institusi yang melayani informasi, pengetahun, dan kearifan yang dapat meningkatkan kemajuan moral dan intelektual-konseptual dan mendirikan lembaga yang menangani integritas akademik ( $\mathrm{p}$. 183).

Oleh sebab itu, ke depan kita secara individu dan masyarakat perlu menggiatkan gerakan melawan nyontek. Para guru dan pengajar atau dosen akan tetap komit untuk melanggengkan gerakan melawan nyontek dan mengajarkan kejujuran kepada siswa-siswi, mahasiswa-mahasiswi. Hal ini hendaknya menjadi kontrak sosial dalam masyarakat sekolah dan masyarakat kampus (p. 186). Selain itu, para guru dan dosen perlu terus menerus mengingatkan siswa-siswi dan mahasiswa-mahasiswi pentingnya belajar (mencari ilmu) sebagai tujuan sekolah atau kuliah, menyontek dapat menghalangi keberhasilan meraih ilmu 
(p. 188).

Dalam bab berikutnya (bab 8) penulis mengajukan bahasan tentang perbaikan taktik dan strategi dalam menangani problem ketidakjujuran akademik di kalangan siswa dan mahasiswa. Memerangi tindakan nyontek karena nyontek (tindak korupsi) merusak penyelenggaraan pendidikan sesuai dengan misi suci dan nyontek merupakan moral decay. Oleh karena itu, tindakan yang radikal untuk memberantas ketidakjujuran akademik perlu dilakukan. Tindakan strategis perlu diinisiasi dan dilakukan dengan disiplin dan cepat. Integritas akademik merupakan bagian dari profesionalisme yang harus diperjuangkan dan dipertahankan oleh guru, dosen, mahasiswa, dan siswa-siswi (p. 191).

Ada lima strategi untuk mewujudkan tujuan, yaitu: pertama, mengartikulasi visi dengan membangun platform preseden berpikir secara nasional dan lokal. Kedua, mengampanyekan bahwa nyontek adalah praktik korupsi yang akan menimbulkan kehancuran masyarakat. Ketiga, menegaskan kembali kepada publik bahwa semua pihak berkomitmen untuk menegakkan integritas akademik dan memerangi korupsi dan nyontek sebagai cikal bakal korupsi. Keempat, berusaha keras untuk melembagakan integritas akademik dengan menjadikan inisiatif menerapakan integritas akadaemik sebagai tujuan strategis di sekolah. Kelima, memasukkan integritas akademik sebagai bagian dari penilaian dan akreditasi untuk menciptakan mekanisme akuntabilitas eksternal (p. 192). Untuk melaksanakan kelima strategi tersebut, penulis mengemukakan enam taktik utama, yaitu: melakukan public pressure kepada pimpinan kampus dan otoritas pendidikan, memastikan atau mengamankan dukungan utama terhadap seluruh eksperimen dan inisiatif untuk mewujudkan teaching excellence, integritas akademik dan integrasi beberapa misi pendidikan, internasionalisasi gerakan integritas akademik (p. 192, 193). Dalam melakukan internasionalisasi gerakan integritas akademik, hal-hal yang akan menjadi tantangan perlu diperhatikan dengan seksama, sehingga upgrade terhadap strategi perlu dilakukan (p. 194). 
Book Review: Cheating in School

Keberhasilan gerakan anti atau melawan nyontek (academic dishonesty) memerlukan dukungan semua pihak. Penulis menjelaskan contoh kontribusi seluruh elemen masyarakat. Orang tua siswa-siswi dapat memberi dukungan antara lain dengan (i) menggunakan pengalaman tentang pekerjaan rumah sebagai kesempatan untuk membicarakan hal-hal yang tepat atau etis dan tidak etis dalam melakukan kerjasama (ii) tidak menekankan anak mendapat angka tinggi (grade) namun menekankan belajar, menumbuhkan dan mengembangkan minat intelektual dan pendidikan, (iii) dorong anak minta bantuan kepada guru atau asisten ketika anak menemukan kesulitan, (iii) membantu anak meningkatkan kemampuan mengelola waktu dan menghindarkan molor waktu yang acapkali membawa anak melakukan nyontek dengan menetapkan waktu untuk menyelesaikan pekerjaan rumah dan mengutamakan waktu untuk kegiatan atau pekerjaan sekolah daripada kegiatan lainnya (p. 195).

Guru (SMP/SMA) memainkan peran dengan melakukan beberapa kegiatan, misalnya (i) membicarakan pentingnya integritas akademik kepada siswa-siswi berulang dalam satu semester dan mewanti-wanti agar para siswa-siswi tidak tergoda nyontek, (ii) bekerjasama dengan orang tua dan melibatkan anak-anak untuk membicarakan etik dan mengajarkan mereka undang-undang hak paten. Hal ini dimaksudkan agar anak-anak tidak hanya tidak melakukan nyontek namun menunjukkan kepada mereka bagaimana melakukan kegiatan yang memenuhi ketentuan etik dan hukum, (iii) memastikan integritas akademik menjadi agenda guru dalam pertemuan tahunan dan mengembangkan pembelajaran, (iv) mengajarkan cara menulis sesuai ketentuan dan etika akademik, (v) dorong orang tua yang suka membantu anaknya menyelesaikan PR alias nyontek untuk tidak melakukan hal tersebut (p. 196).

Administrator dapat melakukan beberapa kegiatan untuk kelangsungan gerakan melawan nyontek, seperti, (i) memasukkan kebijakan dan prosedur integritas akademik dalam program orientasi mahasiswa-mahasiswi, pengajar atau dosen, pembantu 
pimpinan fakultas dan staf, (ii) memastikan bahwa kebijakan dan prosedur integritas akademik jelas dan dikenal civitas dosen, (iii), membangun jaringan dengan jurusan-jurusan yang menjadi champion integritas dan memiliki sumber yang menjadi jaringan, (iii) hati-hati dalam melembagakan integritas akademik di sekolah atau fakultas dan lakukan komunikasi secara intens dengan para pengajar (p. 198).

Untuk perguruan tinggi dan universitas, penulis menjelaskan beberapa contoh kegiatan yang dapat dilakukan untuk membuat gerakan antinyontek (ketidakjujuran akademik) dengan kegiatan antara lain (i) mengurangi kesempatan nyontek dengan mendatangi atau melakukan patroli di tempat ujian yang berjubel untuk memastikan bahwa ujian dan tugas bermanfaat dan dilakukan dengan fair, (ii) perlu dicantumkan secara tegas dalam silabus bahwa integritas akademik itu penting dan kerjasama dalam menyelesaikan latihan, proyek dan pekerjaan rumah dilarang, (iii) bicarakan integritas akademik berulang kali dalam satu semester, (iv) berbagi dengan mahasiswa-mahasiswi materi-materi dan sumber rujukan kuliah sehingga mahasiswamahasiswi tahu founding father intelektual dalam ilmu yang dipelajari, (v) secara konsisten melaporkan mahasiswa-mahasiswi yang melanggar kebijakan integritas kampus. Dengan cara demikian mahasiswa-mahasiswi belajar perilaku yang secara etika akademik diperbolehkan dan tidak diperbolehkan (p. 198).

Kepala sekolah dan rektor melakukan beberapa kegiatan untuk mendukung gerakan melawan nyontek, seperti (i) harus memiliki data yang baik tentang keadaan atau tindakan nyontek di kampus, pemahaman yang sama tentang langkah pelembagaan gerakan ini yang terjadi di sekolah/kampus, rencana untuk melindung kemajuan dan atau langkah-langkah lanjut untuk memantapkan pelembagaan gerakan ini pada tingkat lebih tinggi ( $\mathrm{p}$. 198), (ii) menjadikan integritas akademik sebagai bagian yang tidak terpisahkan dari "sejarah" kampus, perannya dalam misi pengajaran dan riset, dan nilai untuk mahasiswa-mahasiswi, dosen, alumni, dan masyarakat umum, (iii) memasukan integritas akademik dalam ujian dan self studies di kampus (p. 199). 
Anggota majelis perguruan tinggi dan komite sekolah dapat melakukan beberapa kegiatan untuk mendukung gerakan melawan nyontek, antara lain (i) meminta pimpinan/rektor mengawasi capaian kelembagaan gerakan di kampus dan apa yang tengah dilakukan dalam menggalakkan gerakan antinyontek, (ii) bawa topik atau isu integritas akademik ke donor, alumni, dan teman-teman sekolah yang tengah menguji reaksi dan mengkomunikasikan topik ini, (iii) memberikan dukungan kepada rektor/kepala sekolah untuk memastikan gerakan anti-nyontek berjalan: pastikan konsistensi apa yang diucapakan dan realita, kurangi jumlah murid atau mahasisiwa per kelas, pastikan dalam pembelajaran atau perkuliahan, riset dan administrasi tidak terjadi misconducts seperti nyontek dan sejenisnya (p. 200).

Kelompok advokasi dapat melakukan beberapa kegiatan untuk mendukung gerakan antinyontek, seperti, (i) The Center for Academic Integrity and Josephson Institute for Ethics mengembangkan jaringan yang kuat untuk aksi yang memajukan integritas akademik, (ii) sebagaimana disarankan David Callahan, isu integritas akademik dibawa proses politik melalui lobi dengan wakil-wakil rakyat yag mempunyai perhatian terhadap integritas akademik-secara pribadi, professional dan politik-isu karakter, kepemimpinan moral dan pendidikan ke depan, (iii) mengembangkan usaha organisasi secara internasional lebih agresif seperti CAI di Kanada (p. 201).

Sedangkan lembaga di luar sekolah/perguruan atau lembaga asing (internasional) dapat melakukan kegiatan-kegiatan, seperti (i) badan akreditasi dapat meminta atau menuntut data statistik tentang nyontek dan korupsi, (ii) badan pengujian atau evaluasi dapat meminta sekolah-sekolah mengukur nyontek terutama berkaitan dengan belajar siswa-siswi, struktur kelembagaan, perilaku guru dan budaya lembaga, (iii) Transparency International dan lembaga sejenis yang menilai integritas atau korupsi dapat memasukkan nyontek di kalangan siswa-siswi sebagai tindak korupsi dan menilai institusi pendidikan di dunia berkaitan dengan nilai integritas lembaga tersebut (p. 188). 